L. Barbieri, I. Lancellotti, T. Manfredini, G.C. Pellacani, J.Ma. Rincón, M. Romero. Nucleation and Crystallization of New Glasses from Fly Ash Originating from Thermal Power Plants Journal of the American Ceramic Society, 84 (2001) 8, 1851-1858

\title{
Nucleation and Crystallization of New Glasses from Fly Ash Originating from Thermal Power Plants
}

\author{
Luisa Barbieri,* Isabella Lancellotti, Tiziano Manfredini,* and Gian Carlo Pellacani* \\ Department of Chemistry, Faculty of Engineering, University of Modena and Reggio Emilia, \\ 41100 Modena, Italy
}

Jesús Ma. Rincón and Maximina Romero

Instituto E. Torroja de Ciencias de la Construcción (The Glass-Ceramic Laboratory), CSIC, 28033 Madrid, Spain

\begin{abstract}
The nucleation and crystallization kinetics of new glasses obtained by melting mixtures of a Spanish carbon fly ash with glass cullet and dolomite slag at $1500^{\circ} \mathrm{C}$ has been evaluated by a calculation method. These glasses, whose microstructure was examined by TEM carbon replica, were susceptible to controlled crystallization in the $800^{\circ}-1100^{\circ} \mathrm{C}$ range. The resulting glassceramics developed acicular and branched wollastonite crystals or a network of dendritic pyroxene mixed with anorthite feldspar (SEM and EDX analysis). The time-temperaturetransformation curves (processing of the XRD data) showed the crystallization kinetics and the critical cooling rate to be in the $12^{\circ}-42^{\circ} \mathrm{C} / \mathrm{min}$ range.
\end{abstract}

\section{Introduction}

The increasing production of fly ash wastes from carbon combustion in thermal power plants has compounded environmental and economical problems worldwide. Storage of these wastes has recently become more restricted because of increasing regulatory laws and the increasing costs of landfilling. ${ }^{1,2}$ It is worth considering acquired experience in the inertization and immobilization of nuclear wastes by vitrification and controlled devitrification to obtain stable glasses and glass-ceramics for the inertization and/or recycling of this fly ash. ${ }^{3,4}$ Although other 
L. Barbieri, I. Lancellotti, T. Manfredini, G.C. Pellacani, J.Ma. Rincón, M. Romero. Nucleation and Crystallization of New Glasses from Fly Ash Originating from Thermal Power Plants Journal of the American Ceramic Society, 84 (2001) 8, 1851-1858

DOI: 10.1111/j.1151-2916.2001.tb00926.x

uses have been proposed for this ash, such as filler components of cements, ${ }^{5}$ fertilizers, and in road construction, ${ }^{6}$ its glassy character makes it a good candidate as a raw material for glassceramic production. In fact, the Sorg and Lurgi companies have recently proposed a vitrification process for fly ashes, where all types of residues are melted jointly in the same batch (SOLUR glass-melting process). ${ }^{7}$ Fly ash is the solid finely subdivided byproduct transported from the gases emitted by the combustion process in thermal power plants and recovered by filtering operations. It is basically composed of $\mathrm{SiO}_{2}, \mathrm{Al}_{2} \mathrm{O}_{3},\left(\mathrm{FeO}+\mathrm{Fe}_{2} \mathrm{O}_{3}\right)$, alkaline and alkaline-earth oxides plus several heavy metals and transition metal oxides.2 The majority of fly ash can be classified into two groups: (i) aluminosilicate ash coming from fossil carbons and (ii) calcium sulfate ash coming from lignite carbons. The first group is closer in composition to the earth's crust (basaltlike), and it is the most common ash. This aluminosilicate ash consists of $60 \%-80 \%$ vitreous spheres with the remainder composed of crystalline bulles. Half of the silicon is present as amorphous and crystalline silica ( $\alpha$-quartz). Mullite $\left(3 \mathrm{Al}_{2} \mathrm{O}_{3} \cdot 2 \mathrm{SiO}_{2}\right)$ and magnetite $\left(\mathrm{Fe}_{3} \mathrm{O}_{4}\right)$ and/or hematite $\left(\alpha-\mathrm{Fe}_{2} \mathrm{O}_{3}\right)$ are also present. The Spanish fly ash is more vitreous $(<90 \%)$, and it can contain anhydrite $\left(\mathrm{CaSO}_{4}\right)$ or portlandite $\left(\mathrm{Ca}(\mathrm{OH})_{2}\right)$, depending on its calcium content. ${ }^{5}$

Although several applications have been proposed for the recycling of fly ash, not much work has been done on the use of fly ash for glass and glass-ceramic production. Partly crystalline materials (glass-ceramics) can be obtained by the following two alternative thermal cycles: (i) petrological processing and (ii) glass-ceramic processing. In glass-ceramic ("sensu stricto") processing, an original glass is obtained via melting and rapid quenching. After obtaining the glass, the material is heat-treated in one- or, more frequently, two-step nucleation and growth of crystalline phases. In the petrological process, the melt is cooled slowly from melting to room temperature into the original mold. During the cooling part of the thermal cycle, both nucleation and crystal growth steps are accomplished. ${ }^{8}$

The controlled vitrification/devitrification process is a very versatile method, allowing for a wide range of semicrystalline materials because of the variety of compositions for the manufacture of glass-ceramics. Igonet ${ }^{9}$ gives the following general range for glass-ceramic production in the aluminosilicate system: (5-40) $\mathrm{Al}_{2} \mathrm{O}_{3}-(40-75) \mathrm{SiO}_{2}$ (wt\%), with other minor oxides, such as $\mathrm{B}_{2} \mathrm{O}_{3}<10, \mathrm{Li}_{2} \mathrm{O}<15, \mathrm{CaO}<35,\left(\mathrm{Na}_{2} \mathrm{O}+\mathrm{K}_{2} \mathrm{O}\right)<20, \mathrm{MgO}<30, \mathrm{TiO}_{2}<20, \mathrm{ZnO}<30$, and $\mathrm{ZrO}_{2}<25$. This range can be fulfilled by a lot of natural raw materials, wastes, and their mixtures. 
L. Barbieri, I. Lancellotti, T. Manfredini, G.C. Pellacani, J.Ma. Rincón, M. Romero. Nucleation and Crystallization of New Glasses from Fly Ash Originating from Thermal Power Plants Journal of the American Ceramic Society, 84 (2001) 8, 1851-1858

DOI: 10.1111/j.1151-2916.2001.tb00926.x

The capacity of borosilicate and aluminoborosilicate glasses to immobilize inorganic radioactive products for nuclear waste management is well-known. ${ }^{10,11}$ It has been shown that the glassceramic matrixes, specifically those designed to develop basalt compositions, are the best, ${ }^{12}$ because they show low leaching velocity and are very stable.

The objective of this research has been to investigate the kinetics of nucleation and crystal growth capability of new, previously characterized glasses obtained from fly ash from a Spanish thermal power plant. ${ }^{13}$ The evolution of phase formation and the microstructure changes with time-temperature-transformation (TTT) thermal treatments have been studied as well.

\section{Experimental Procedure}

Among the different Spanish thermal plant fly ashes analytically and physically characterized in a previous investigation, ${ }^{14}$ the most representative in composition with a tendency toward devitrification was chosen. The percentage of $\mathrm{Fe}_{2} \mathrm{O}_{3}$ nucleation agent greatly affected this fly ash's (As Pontes) ability to nucleate and crystallize after glass forming. After calcination at $1000^{\circ} \mathrm{C}$ for $30 \mathrm{~min}$, this fly ash was mixed with float dolomite (Asturiana del Zinc, SA, Asturias, Spain) coming from zinc extraction operations and glass cullet (from the recovery national system). These raw materials (whose analyses were obtained previously) ${ }^{13}$ were mixed to formulate the three different glasses investigated (Table I).

As shown in a previous paper, ${ }^{13}$ two families of glasses were obtained depending on their composition and crystallization behavior, viz., (i) glasses 5AP on 6AP from the basic composition system $\mathrm{Na}_{2} \mathrm{O}-\mathrm{CaO}-\mathrm{Al}_{2} \mathrm{O}_{3}-\mathrm{SiO}_{2}$ and (ii) glass 4AP from the basic composition system $\mathrm{CaO}-\mathrm{MgO}-\mathrm{Fe}_{2} \mathrm{O}_{3}-\mathrm{Al}_{2} \mathrm{O}_{3}-\mathrm{SiO}_{2}$. All glasses were obtained using the same procedure: melting at $1500^{\circ} \mathrm{C}$ for $5 \mathrm{~h}$ in a super Kanthal furnace and molding by pouring in brass molds.

Diagrams of the "petrological" trend from Russian authors ${ }^{15,16}$ were examined to determine the tendency of obtaining glassceramics within this system before performing thermal analysis experiments on nucleation and crystal growth. Using the "sensu stricto" glass-ceramic process, devitrification behavior might be more favored for these original glasses because of the longer controlled heat treatments used in the classical process for glassceramic production. 
L. Barbieri, I. Lancellotti, T. Manfredini, G.C. Pellacani, J.Ma. Rincón, M. Romero. Nucleation and Crystallization of New Glasses from Fly Ash Originating from Thermal Power Plants Journal of the American Ceramic Society, 84 (2001) 8, 1851-1858

DOI: 10.1111/j.1151-2916.2001.tb00926.x

Table I. Formulated and EDX average composition of main components (as oxides) and light element analysis performed from original glasses

\begin{tabular}{|c|c|c|c|c|c|c|}
\hline \multirow[b]{3}{*}{ Component } & \multicolumn{6}{|c|}{ Average composition (wt $\%$ ) } \\
\hline & \multicolumn{2}{|c|}{$4 \mathrm{AP}$} & \multicolumn{2}{|c|}{$5 \mathrm{AP}$} & \multicolumn{2}{|c|}{$6 \mathrm{AP}$} \\
\hline & Formulated & EDX & Formulated & EDX & Formulated & EDX \\
\hline \multicolumn{7}{|c|}{ Analysis of oxides } \\
\hline $\mathrm{SiO}_{2}$ & 48.64 & 67.85 & 67.97 & 83.61 & 65.67 & 85.30 \\
\hline $\mathrm{Al}_{2} \mathrm{O}_{3}$ & 16.94 & 11.94 & 4.80 & 4.88 & 7.51 & 3.04 \\
\hline $\mathrm{CaO}$ & 15.74 & 13.47 & 11.54 & 7.20 & 11.29 & 6.97 \\
\hline $\mathrm{MgO}$ & 6.58 & 2.46 & 2.65 & 0.58 & 2.62 & 0.87 \\
\hline $\mathrm{Na}_{2} \mathrm{O}$ & 4.28 & 1.01 & 10.78 & 2.60 & 9.67 & 2.89 \\
\hline $\mathrm{K}_{2} \mathrm{O}$ & 0.89 & 0.68 & 0.86 & 0.47 & 0.89 & 0.33 \\
\hline $\mathrm{Fe}_{2} \mathrm{O}_{3}^{\dagger}$ & 6.26 & 2.34 & 1.22 & 0.55 & 2.16 & 0.30 \\
\hline $\mathrm{TiO}_{2}$ & 0.67 & 0.25 & 0.18 & 0.11 & 0.29 & 0.30 \\
\hline \multicolumn{7}{|c|}{ Light element analysis ${ }^{I}$} \\
\hline Nitrogen & & & \multicolumn{2}{|c|}{0.00} & \multicolumn{2}{|c|}{0.08} \\
\hline Carbon & \multicolumn{2}{|c|}{0.19} & \multicolumn{2}{|c|}{0.20} & \multirow{2}{*}{\multicolumn{2}{|c|}{$\begin{array}{l}0.24 \\
0.05\end{array}$}} \\
\hline Hydrogen & \multicolumn{2}{|c|}{0.06} & \multicolumn{2}{|c|}{0.05} & & \\
\hline
\end{tabular}

Thermal behavior studies determining the characteristic temperatures of glass transition (Tg), crystallization (TC), and melting (TL) were conducted on DTA equipment (Model DSC 404, Netzsch, Selb, Germany) using 30 mg of powdered glass (grain size $<35 \mathrm{~mm}$ ). These studies were conducted using a platinum crucible in air atmosphere from $20^{\circ}$ to $1400^{\circ} \mathrm{C}$ with a heating rate of $10^{\circ} \mathrm{C} / \mathrm{min}$. Analysis of the thermal data with the well-known derivative DTA (DDTA) method enabled the detection and determination of the glasses’ crystallization tendencies. ${ }^{17}$

After molding glasses in prismatic bars ( $4 \mathrm{~mm} \times 4 \mathrm{~mm}$ sections), several specimens of the same size (10 mm x $4 \mathrm{~mm}$ x $4 \mathrm{~mm}$ ) were cut and their faces polished to perform time-temperatureheat treatments. The thermal treatments were performed by introducing the glass specimen at each temperature and quenching directly in air after the appropriate time lapse for each TTT heat treatment. The nature (amorphous or crystallized) of each specimen obtained, as well as the original glasses and the synthesized phases, were then characterized by an X-ray powder diffractometer (Model PW 3710, Philips, Eindhoven, The Netherlands).

Microstructural observations and compositional microanalysis were conducted by SEM and Xray microanalysis (EDX) when necessary for determining the average composition of the specimen. Spot analysis in crystals and/or areas, when possible, was conducted to differentiate, within the limited analytical resolution of the SEM/EDX system (Model JSM-V3/Link EDX, Jeol, Tokyo, Japan), the phases that constituted the final glass-ceramic. Specimens for SEM were prepared by embedding them in epoxy resin and polishing with $\mathrm{SiC}$ of different grain sizes to $\mathrm{Al}_{2} \mathrm{O}_{3}$ paste $(0.5-0.3 \mathrm{~mm})$. 
L. Barbieri, I. Lancellotti, T. Manfredini, G.C. Pellacani, J.Ma. Rincón, M. Romero. Nucleation and Crystallization of New Glasses from Fly Ash Originating from Thermal Power Plants Journal of the American Ceramic Society, 84 (2001) 8, 1851-1858

DOI: 10.1111/j.1151-2916.2001.tb00926.x

Chemical analysis of nitrogen, carbon, hydrogen, and sulfur was performed in the original glasses by an elemental analyzer (Model 1106, Carlo Erba, Milan, Italy).

\section{Results and Discussion}

Table I shows the theoretical composition of the original glasses formulated from the abovementioned raw materials and the corresponding average EDX analysis. All the glasses investigated are located in the basic composition system $\mathrm{CaO}-\mathrm{Al}_{2} \mathrm{O}_{3}-\left(\mathrm{FeO}+\mathrm{Fe}_{2} \mathrm{O}_{3}\right)-\mathrm{SiO}_{2}$. Very low concentrations of $\mathrm{TiO}_{2}(0.1-0.3 \mathrm{wt} \%)$ are also detected by EDX analysis, and very low concentrations of $\mathrm{Cr}_{2} \mathrm{O}_{3}(0.03-0.09$, not detected by EDX) are also present in the glasses derived from the glass cullet.

\section{(1) Fly Ash Capability to Produce Glass-Ceramics}

The tendency of the original glasses to devitrify to glassceramics was examined theoretically before initiating experimental work. The final glass-ceramics should comprise a highcrystalline phase volume fraction containing finely textured crystal. These crystals should be $<1 \mu \mathrm{m}$ and homogeneously dispersed. There was the possibility of the presence of a pyroxene structure embedded in a minor portion of the residual glassy phase. Plagioclase crystallization could also occur in the final products, because it is usually seen in commercial high-abrasion-resistant basaltic glass-ceramics. ${ }^{12}$

In principle, according to the chemical composition of these materials, the following phases could be obtained: anorthite $\left(\mathrm{CaO}-\mathrm{Al}_{2} \mathrm{O}_{3}-2 \mathrm{SiO}_{2}\right)$, calcium ferrite $(\mathrm{FeO}-\mathrm{CaO})$, wollastonite $\left(\mathrm{CaO}-\mathrm{SiO}_{2}\right)$, gehlenite $\left(\mathrm{CaO}-\mathrm{Al}_{2} \mathrm{O}_{3}-\mathrm{SiO}_{2}\right)$, diopside $\left(\mathrm{CaO}-\mathrm{MgO}-2 \mathrm{SiO}_{2}\right)$, and/or augite $(\mathrm{CaO}-$ $\left.\mathrm{MgO}-\mathrm{FeO}-\mathrm{SiO}_{2}\right)$. Also, because of the high content of iron oxides, magnetite $\left(\mathrm{FeO}-\mathrm{Fe}_{2} \mathrm{O}_{3}\right)$ and/or hematite $\left(\alpha-\mathrm{Fe}_{2} \mathrm{O}_{3}\right)$ could be precipitated from the glassy matrix. On the other hand, the presence of small impurities, such as $\mathrm{Cr}_{2} \mathrm{O}_{3}, \mathrm{TiO}_{2} \ldots$, can favor the development of the abovementioned ideal microstructure because of their nucleating capabilities. 
L. Barbieri, I. Lancellotti, T. Manfredini, G.C. Pellacani, J.Ma. Rincón, M. Romero. Nucleation and Crystallization of New Glasses from Fly Ash Originating from Thermal Power Plants Journal of the American Ceramic Society, 84 (2001) 8, 1851-1858

DOI: 10.1111/j.1151-2916.2001.tb00926.x

For a long time, petrological criteria have been applied by Russian authors to establish the capability of a mixture of minerals or rocks to produce glass-ceramics. ${ }^{18}$ The Ginsberg method $(1959)^{19}$ uses a ternary diagram to represent the compositions of the original glasses $\mathrm{Sal}\left(\mathrm{SiO}_{2}+\right.$ $\left.\mathrm{Al}_{2} \mathrm{O}_{3}\right)$, Cafem $\left(\mathrm{CaO}+\left(\mathrm{FeO}+\mathrm{Fe}_{2} \mathrm{O}_{3}\right)+\mathrm{MgO}\right)$, and Alk $\left(\mathrm{Na}_{2} \mathrm{O}+\mathrm{K}_{2} \mathrm{O}\right)$. Basically, only glasses located between the $60 \%-70 \%$ Sal band are considered suitable for producing good glassceramics. The glass compositions below this zone contain excessive modifiers that destabilize the glass network. Those with higher $\mathrm{SiO}_{2}$ content have a very rigid structure, making processing operations difficult. Experimental data (Fig. 1(a)) show that all the glassy compositions are close to the ideal band. Composition 4AP seems to be one of the more adequate compositions for producing glass-ceramics.

Another well-known method is the Raschin-Tschetveritkov method (1964) ${ }^{20}$ modified by Kanazirsky and Yotzo in $1972 .{ }^{21}$ In this case, the triangular diagram corresponds to the corners: $\mathrm{Q}, \mathrm{L}$, and $\mathrm{M}$, where $\mathrm{Q}$ is $\mathrm{SiO}_{2}, \mathrm{~L}$ is $\mathrm{Al}_{2} \mathrm{O}_{3}+\mathrm{Na}_{2} \mathrm{O}+\mathrm{K}_{2} \mathrm{O}$, and $\mathrm{M}$ is $\mathrm{CaO}+\mathrm{MgO}+(\mathrm{FeO} 1$ $\left.\mathrm{Fe}_{2} \mathrm{O}_{3}\right)+\mathrm{TiO}_{2}$. This diagram is divided into three zones limited by tie lines: pyroxene-feldspar and pyroxene-Tschermark molecule (Tsch, $\left.\mathrm{CaAlSi}_{2} \mathrm{O}_{6}\right){ }^{22}$ The pyroxene (P) and feldspar (Fd) positions correspond to their theoretical compositions. The glasses located in the Q-P-Fd region have excess $\mathrm{SiO}_{2}$ and are not adequate because of their high viscosity on molding. More suitable glasses are located inside or near the line $\mathrm{P}-\mathrm{Tsch}\left(25 \mathrm{wt} \%\right.$ residual $\left.\mathrm{SiO}_{2}\right)$ and inside the triangle $\mathrm{P}-\mathrm{Fd}-\mathrm{Tsch}$. The compositions under the $\mathrm{P}-\mathrm{Tsch}$ line are inadequate, because they precipitate olivine crystals. ${ }^{15}$ Glasses obtained from fly ash are far away from this ideal triangle (Fig. 1(b)). In any case, 5AP and 6AP are close to the quartz corner, which is related to higher viscosity on melting and controlled crystallization. Although outside the ideal triangle, 4AP is closer to the P-Tsch molecule tie line, making it more adequate for a controlled crystallization process according to this criterium.

Finally, Lebedeva et al., $1979,{ }^{18}$ modified the above diagram by considering the role of modifier cations in the crystallization process, viz., $\mathrm{Ca}^{2+}, \mathrm{Mg}^{2+}$, and $\mathrm{Fe}^{2+}$. Thus, the Lebedeva diagram ${ }^{18}$ considers the following corners: $\mathrm{MG}, \mathrm{CA}$, and $\mathrm{FE}$, where $\mathrm{MG}=\mathrm{Mg}^{2+}, \mathrm{CA}=\mathrm{Ca}^{2+}$, and $\mathrm{FE}=$ $\mathrm{Fe}^{2+}+\mathrm{Fe}^{3+}$. This ternary diagram is divided into six zones according to the appearance of crystalline phases. Consequently, glasses located in zone I give rise to magnetite $\left(\mathrm{Fe}_{3} \mathrm{O}_{4}\right)$ surrounded by spherulitic pyroxene crystals. Inside zone II, magnetite is not the primary phase, giving rise to materials where pyroxene could coexist with secondary magnetite. Zones III to V are very similar in microstructural composition. However, if $\mathrm{L}>\mathrm{M}$, plagioclase crystallizes as the primary phase; conversely, if $\mathrm{L}<\mathrm{M}$, pyroxene is the first phase. Finally, zone VI produces 
L. Barbieri, I. Lancellotti, T. Manfredini, G.C. Pellacani, J.Ma. Rincón, M. Romero. Nucleation and Crystallization of New Glasses from Fly Ash Originating from Thermal Power Plants Journal of the American Ceramic Society, 84 (2001) 8, 1851-1858

olivine, which is not adequate for glass-ceramic production. This diagram indicates that all glasses considered in this study would be outside any field for the development of "petrological” materials (Fig. 1(c)). In any case, according to the Lebedeva criterium, the most probable crystalline phase obtained from these glasses would be pyroxene.

The three methods are complementary, because we are not allowed to define what is the "best" composition for glass-ceramic production. Thus, the Ginsberg method gives us an idea of the role played by cations in the crystallization process. Similarly, the Raschin and Lebedeva methods give us information about the nature and sequence of crystallization.
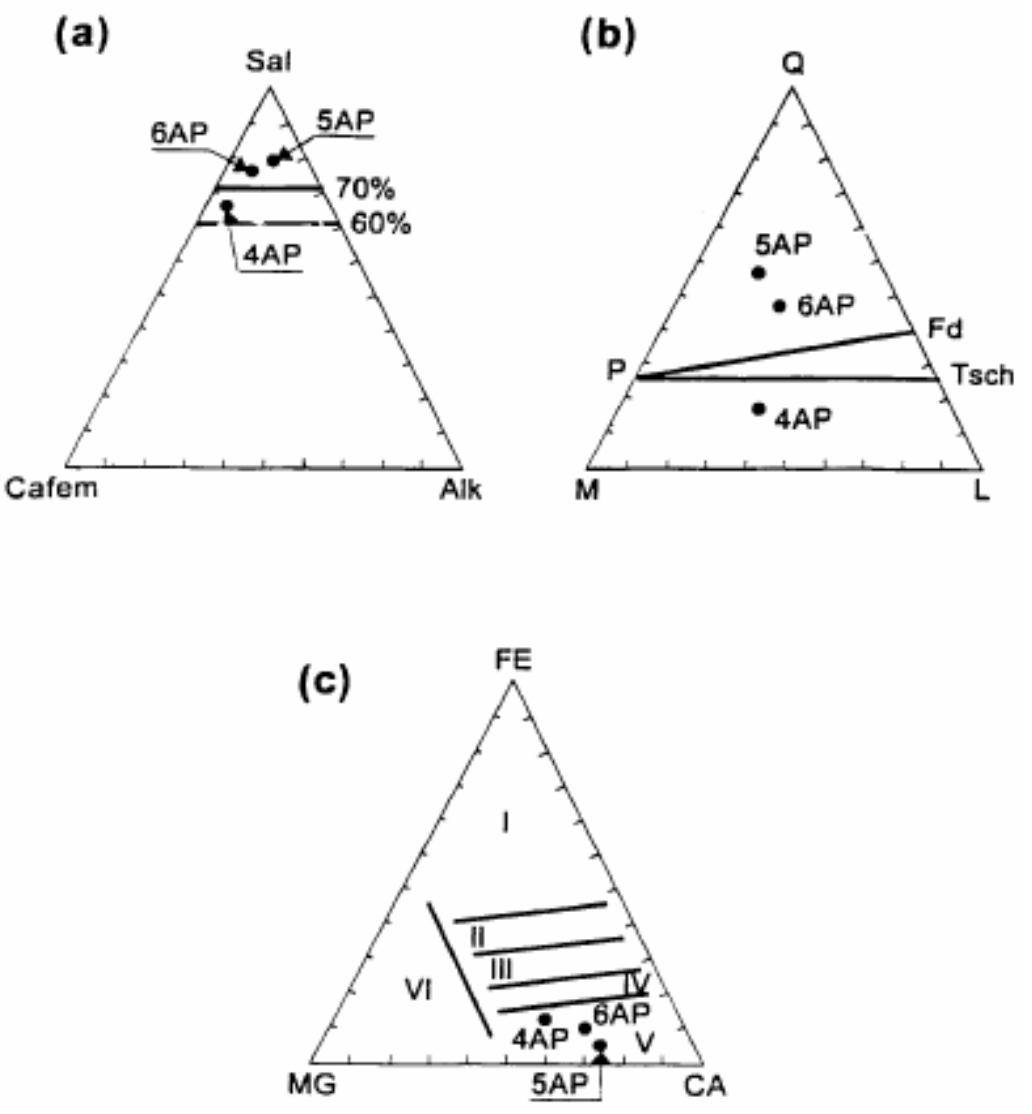

Fig. 1. Diagrams used to study glasses' capability to transform into glass-ceramic materials. Compositions of glasses synthesized from Spanish fly ash are located inside (a) Ginsberg, (b) Raschin-Tschetveritkov, and (c) Lebedeva diagrams.

It is important to note that, and as will be seen in the following paragraphs, only experimental thermal behavior can give the actual trend for crystallization in these complex glasses. 
L. Barbieri, I. Lancellotti, T. Manfredini, G.C. Pellacani, J.Ma. Rincón, M. Romero. Nucleation and Crystallization of New Glasses from Fly Ash Originating from Thermal Power Plants Journal of the American Ceramic Society, 84 (2001) 8, 1851-1858

DOI: 10.1111/j.1151-2916.2001.tb00926.x

\section{(2) Thermal Behavior of Original Glasses}

DTA experiments were conducted on the glasses considered and were published previously. ${ }^{13}$ These glasses showed different tendencies toward crystallization: 5AP and 6AP glasses were more thermally stable, showing the glass transition (Tg) at $\sim 600^{\circ} \mathrm{C}$ with no exothermic peak at high temperatures. After $\mathrm{Tg}$ at $670^{\circ} \mathrm{C}$, the $4 \mathrm{AP}$ glass, conversely, showed a very clear exothermic peak at $890^{\circ} \mathrm{C}$ that corresponded with the formation of a crystalline phase that melted at $1200^{\circ} \mathrm{C}$. To explain the $300^{\circ} \mathrm{C}$ exothermic effect observed in DTA experiments on these glasses, an analysis of nitrogen, carbon, hydrogen, and sulfur was conducted (Table I), showing that sulfur was not found in the detection limits. The $E_{\text {act }}$ was $691 \mathrm{~kJ} / \mathrm{mol}$ for $4 \mathrm{AP}$ glass, while it was not possible to determine this energy for 5AP and 6AP, because they did not show clear exothermic peaks at the heating rate used. ${ }^{17}$

The TTT curves were determined in the glasses investigated to find the relative crystallization ranges as well as devitrification curves of these glasses. The diagrams shown in Fig. 2 were prepared by considering XRD results and taking into account the following criteria: "amorphous" was the heat-treated glass without peaks in the XRD diagram, "onset of crystallization” was when small peaks appeared over the background of the XRD diagram, "partial crystallization" was when these peaks were of increasing intensity, and "total crystallization” when peaks of crystalline phases ceased to grow. A boundary line was drawn between "amorphous" and "onset of crystallization," which allowed us to differentiate the tendency toward crystallization of glasses obtained from the vitrification of fly ash. Thus, it was evident that 4AP glass was well-crystallized with very short thermal treatment times, being $80 \%$ crystallized from $60 \mathrm{~min}$ of treatment at $1100^{\circ} \mathrm{C}$ for pyroxene phase and $\sim 60 \%$ for feldspar phase. The 5AP and 6AP needed at least $8 \mathrm{~h}$ at $1000^{\circ} \mathrm{C}$ for full crystallization. After $2 \mathrm{~h}$ of thermal treatment, 5AP seemed more crystallized than 6AP glass. It is characteristic of the 4AP glass that crystallization started after very short thermal treatment times $(10 \mathrm{~min})$ at $1000^{\circ} \mathrm{C}$.

The TTT curves are valuable not only for determining the kinetics of growth in these glasses but also for determining the minimum cooling rates required to form such types of glass. Usually, the TTT curves are determined and given for specific volume fractions. ${ }^{23}$ In any case, they also allow us to determine the approximate cooling rate required to avoid the detection of phase crystallization by XRD: 
L. Barbieri, I. Lancellotti, T. Manfredini, G.C. Pellacani, J.Ma. Rincón, M. Romero. Nucleation and Crystallization of New Glasses from Fly Ash Originating from Thermal Power Plants Journal of the American Ceramic Society, 84 (2001) 8, 1851-1858

$$
\frac{\mathrm{d} T}{\mathrm{~d} t}=\frac{\Delta T_{N}}{\tau_{N}}
$$

where $\Delta \mathrm{T}_{\mathrm{N}}=\mathrm{T}_{\mathrm{L}}-\mathrm{T}_{\mathrm{N}}$. The $\mathrm{T}_{\mathrm{N}}$ and $\mathrm{t}_{\mathrm{N}}$ are the temperature and time at the nose of the TTT curve, respectively, and $\mathrm{T}_{\mathrm{L}}$ the melting temperature of glass. Therefore, in our case, these nose parameters were estimated, as shown in Table II. To obtain an original glass without appreciable crystallization by XRD, the 4AP glass needs faster cooling rates than 5AP and 6AP glasses. It is even possible to distinguish differences in the glassy tendency between the 5AP and 6AP glasses, which are not detected by DTA experiments. ${ }^{13}$
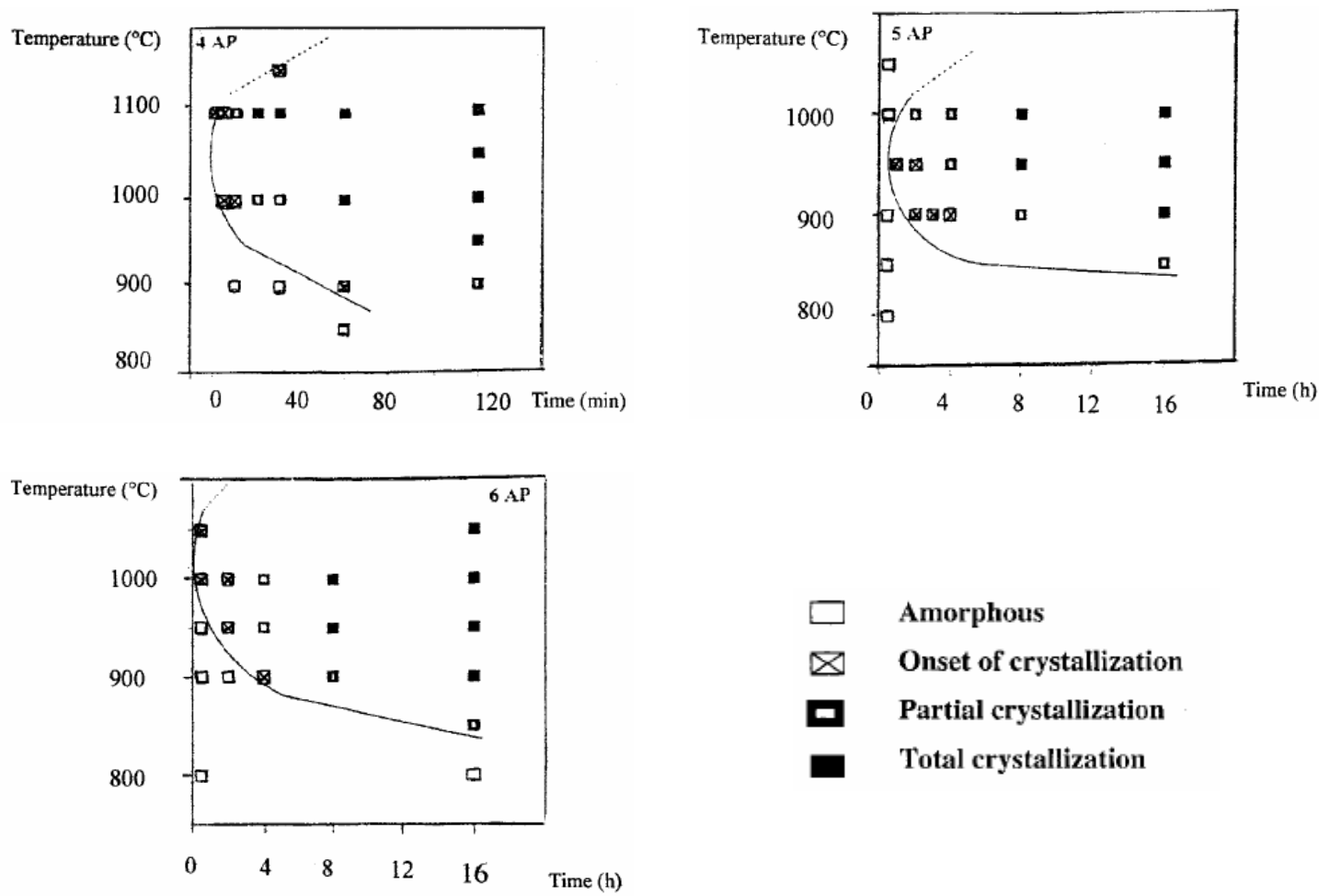

Fig. 2. TTT diagrams obtained from 4AP, 5AP, and 6AP glasses.

Kinetic behavior for glass formation is also related to nucleation frequency $\left(I_{v}\right)$ and rate of advance of crystal-liquid interface $(u)$, according to the well-known equation: ${ }^{23}$

$$
X \cong \frac{1}{3} \pi I_{v} u^{3} t^{4}
$$


L. Barbieri, I. Lancellotti, T. Manfredini, G.C. Pellacani, J.Ma. Rincón, M. Romero. Nucleation and Crystallization of New Glasses from Fly Ash Originating from Thermal Power Plants Journal of the American Ceramic Society, 84 (2001) 8, 1851-1858 DOI: 10.1111/j.1151-2916.2001.tb00926.x

that allows us to determine the volume fraction, $X$, of crystallization for a given time, $t$. The following results show the kinetic behavior of crystalline phases formed from the thermal treatment of the fly ash glasses investigated here.

Table II. Estimation of Critical Cooling Rate of Fly Ash Glasses from GTTT Curves

\begin{tabular}{llll}
\hline \multirow{2}{*}{ Property } & \multicolumn{3}{c}{ Value } \\
\cline { 2 - 4 } & 4AP & 5AP & 6AP \\
\hline Glassy stability ratio $^{\dagger}$ & 1.09 & 2.22 & 2.05 \\
$T_{\mathrm{N}}\left({ }^{\circ} \mathrm{C}\right)$ & 1025 & 950 & 1000 \\
$\tau_{\mathrm{N}}(\mathrm{min})$ & 10 & 40 & 10 \\
$(\mathrm{~d} T / \mathrm{d} t)_{\mathrm{c}}\left({ }^{\circ} \mathrm{C} / \mathrm{min}\right)$ & 42 & 12 & 22 \\
\hline
\end{tabular}

\footnotetext{
TRatio of glass-network-former oxides to glass-network-modifier oxides, given as $\mathrm{SiO}_{2} / \mathbf{2}\left(\mathrm{Na}_{2} \mathrm{O}+\mathrm{K}_{2} \mathrm{O}+\mathrm{CaO}+\mathrm{MgO}+\mathrm{Al}_{2} \mathrm{O}_{3}\right)$. Weight percentages taken from Table I.
}

Figure 3 depicts the relative devitrification curves for different glasses and crystalline phases obtained from this XRD analysis. In fact, the main precipitated crystalline phases in these glasses were different according to their composition, viz., pyroxene and feldspar for the 4AP glass and wollastonite for the 5AP and 6AP glasses. Several of the 4AP glass-ceramics obtained after thermal treatment of the original glass also showed crystallization of magnesioferrite and magnetite.

The evolution of crystalline phase growth with thermal treatment length is similar in other basalt glasses. ${ }^{24}$ The slope in the initial stages of the crystallization process is very steep and does not show induction time for crystallization, as is usual in simpler glasses susceptible to controlled nucleation and crystallization processes. ${ }^{25}$ In all glasses and phases considered here, only the lower-temperature growth $\left(900^{\circ} \mathrm{C}\right)$ is linear, while a paraboloid curve of growth is observed at higher temperatures up to the crystal saturation process. Nevertheless, in some cases, such as for the pyroxene in the $4 \mathrm{AP}$ glass heat-treated at $1100^{\circ} \mathrm{C}$ and the wollastonite in the $5 \mathrm{AP}$ glass heat-treated at $950^{\circ} \mathrm{C}$, there is a smooth decrease of these crystalline phases.

The relative velocity or devitrification curves given in Fig. 3 summarize the global and comparative nucleation and growth behavior of the fly ash glasses investigated. Thus, for the 4AP glass, the pyroxene crystallization rate is higher than the feldspar rate. It seems that pyroxene is the primary crystallization phase from the original melt, the feldspar being 
L. Barbieri, I. Lancellotti, T. Manfredini, G.C. Pellacani, J.Ma. Rincón, M. Romero. Nucleation and Crystallization of New Glasses from Fly Ash Originating from Thermal Power Plants Journal of the American Ceramic Society, 84 (2001) 8, 1851-1858

nucleated from the residual glassy phase in subsequent thermal treatment processes. The crystallization behavior of 5AP and 6AP glass is very similar, giving rise to wollastonite crystals, but the degree of crystallization is greater for 5AP glass.
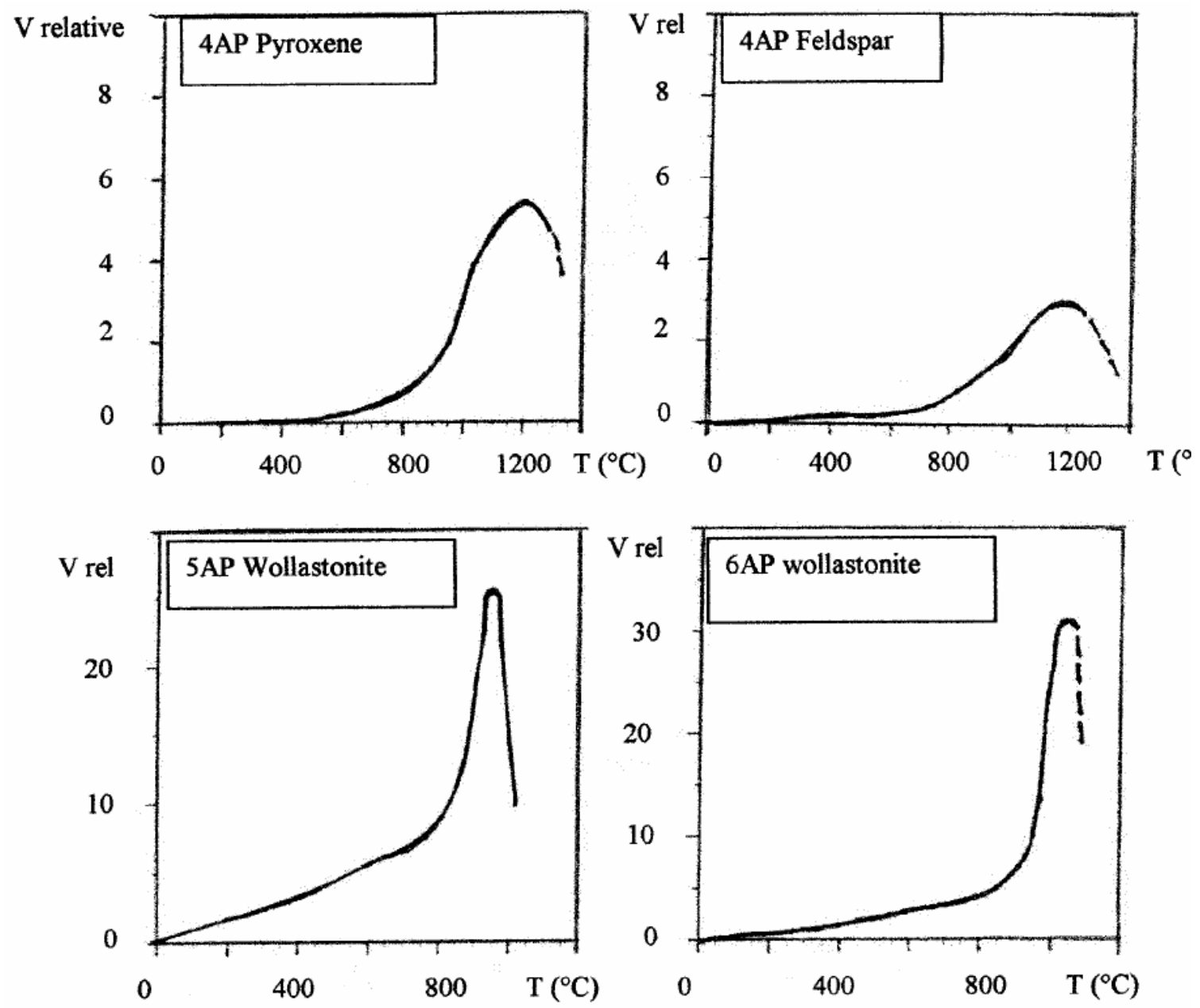

Fig. 3. Relative rate of crystallization determined by XRD for different phases: pyroxene and feldspar from 4AP glass, and wollastonite from 5AP and 6AP glasses.

The significantly greater tendency of $4 \mathrm{AP}$ glass to crystallize with respect to 5AP and 6AP glasses can be explained by considering the composition ratio of the glass-network oxide $\left(\mathrm{SiO}_{2}\right)$ to the modifier oxides of the glass network, i.e., $\mathrm{Na}_{2} \mathrm{O}+\mathrm{K}_{2} \mathrm{O}+\mathrm{CaO}+\mathrm{MgO}+\mathrm{Al}_{2} \mathrm{O}_{3}{ }^{3,25}$ As can be seen in Table II, where this ratio has been included, after calculation from the data of the formulated composition (Table I), these ratios are 1.09, 2.22, and 2.05 for the glasses investigated. According to the relative tendency to crystallize, this value is lower for 4AP, which indicates a high tendency to crystallize. Usually, by considering the average composition 
L. Barbieri, I. Lancellotti, T. Manfredini, G.C. Pellacani, J.Ma. Rincón, M. Romero. Nucleation and Crystallization of New Glasses from Fly Ash Originating from Thermal Power Plants Journal of the American Ceramic Society, 84 (2001) 8, 1851-1858

DOI: 10.1111/j.1151-2916.2001.tb00926.x

of conventional glasses (float and bottle glass), this ratio is $\sim 2.50$, which is in agreement with the high stability of these glasses. Even more, the difference in the stability ratio between 5AP and 6AP allows us to explain the higher relative stability of 5AP with respect to 6AP glass.

On the other hand, even though there was a low percentage of crystalline phase obtained after thermal treatment of 5AP and 6AP glasses, the final materials that cover a wide range of volume fractions of crystals can be considered glass-ceramics. It is well-known that the glass-ceramic concept covers a wide range of crystallinity percentage from transparent to opaque materials. $^{24,25}$

\section{(3) Microstructure and Phases Analysis}

(A) Original Glasses: Figures 4(a)-(c) depict TEM micrographs (carbon direct replica method) conducted on the 4AP, 5AP, and 6AP parent glasses formed from Spanish fly ash. The different microstructures of these glasses can be seen, being separated into liquid phases but to a different extent, depending on the original composition. 4AP, which is more susceptible to phase crystallization, shows microheterogeneities with very small nuclei and some initial crystallization in the glassy matrix. 5AP has very homogeneously distributed droplets of phase separation, while 6AP shows heterogeneously distributed phase separation, having a texture indicative of a mixture of two glassy phases: one without phase separation and the other with droplets of different sizes. To obtain more information on the comparative structure of the original glasses, infrared spectroscopy was conducted between $4000-490 \mathrm{~cm}^{-1}$. The corresponding spectra are shown in Fig. 5. These results confirm the different structures of the original glasses investigated, although the bands of $\mathrm{Al}-\mathrm{O}$ and $\mathrm{Si}-\mathrm{O}-\mathrm{Si}$ bonds between 1000$490 \mathrm{~cm}^{-1}$ are very similar. Thus, 4AP and 5AP give small bands at 3500 and $1700 \mathrm{~cm}^{-1}$, which are well-known to be related to the $\mathrm{O}-\mathrm{H}$ groups, but the shape of these bands is different in both glasses. The 5AP glass shows a very wide band between 2000 and $1000 \mathrm{~cm}^{-1}$, which does not appear in the similar 6AP glass. This could be related to the large extension and homogeneity of the glass-in-glass phase separation observed by TEM in this glass, ${ }^{26}$ indicating a strong difference between 5AP and 6AP glasses. 
L. Barbieri, I. Lancellotti, T. Manfredini, G.C. Pellacani, J.Ma. Rincón, M. Romero. Nucleation and Crystallization of New Glasses from Fly Ash Originating from Thermal Power Plants Journal of the American Ceramic Society, 84 (2001) 8, 1851-1858
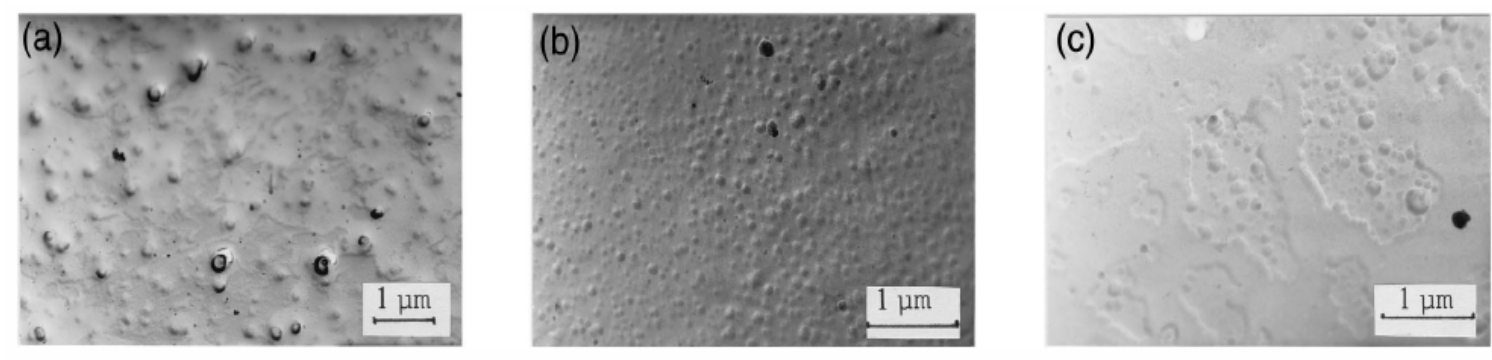

Fig. 4. TEM carbon direct replica observations from original glasses: (a) 4AP glass at 10260 magnification, (b) 5AP glass at 15960 magnification, and (c) 6AP glass at 15960 magnification.

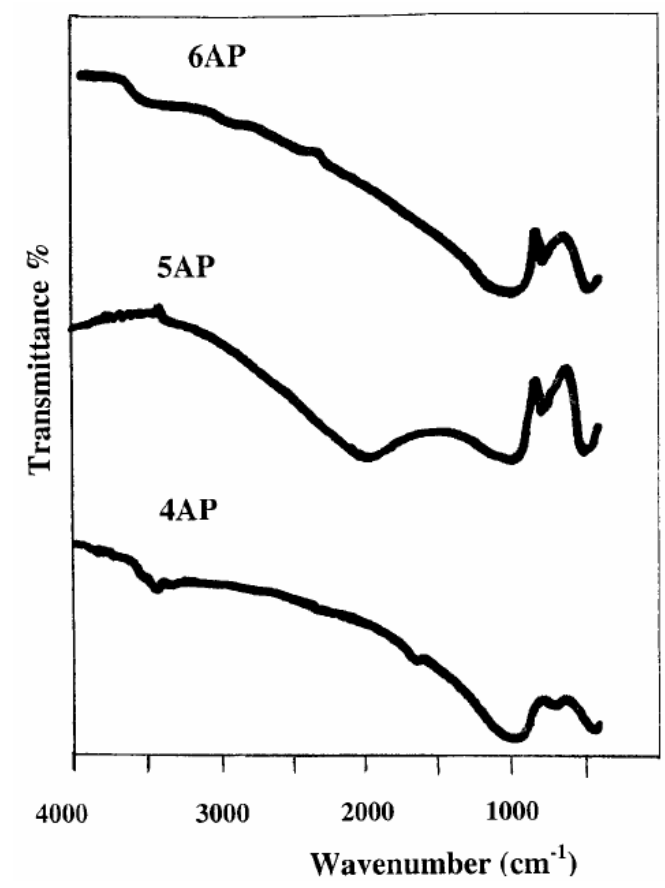

Fig. 5. Infrared spectra from 4AP, 5AP, and 6AP original glasses.

(B) Glass-Ceramics: More detailed information on the nature and composition of the crystalline phases present in heat-treated glasses (glass-ceramics) has been obtained by SEM/EDX observations after TTT treatments. The DTA, TTT, and XRD results confirm that the tendency toward crystallization is in the following order: 4AP $>5 \mathrm{AP}>6 \mathrm{AP}$. Figure 6 shows a micrograph from some of the SEM observations conducted in glass-ceramics obtained from the 4AP glass after $2 \mathrm{~h}$ of thermal treatment. The evolution of dendritic crystallization of pyroxene 
L. Barbieri, I. Lancellotti, T. Manfredini, G.C. Pellacani, J.Ma. Rincón, M. Romero. Nucleation and Crystallization of New Glasses from Fly Ash Originating from Thermal Power Plants Journal of the American Ceramic Society, 84 (2001) 8, 1851-1858

DOI: 10.1111/j.1151-2916.2001.tb00926.x

crystals is evident from $900^{\circ}$ to $1100^{\circ} \mathrm{C}$; crystals of pyroxene nucleate oriented from the surface and from the bulk of the specimen.

Dendritic growth starts at $900^{\circ} \mathrm{C}$, and the specimen is covered with dendritic crystallization, indicated by the white contrast due to the high atomic number element (basically iron oxide) content. At $1000^{\circ} \mathrm{C}$, precipitation of white contrast acicular crystals of feldspar phase occurs together with dendritic growth, which is more oriented toward the fibril axis with an angle very close to $90^{\circ}$. The axis of the fibrils shows whiter contrast than the branches because of the diffusion of iron oxide, as is usual in dendritic growth mechanisms. ${ }^{27}$ After higher-temperature thermal treatments, the glassy phase content increases. The size of crystallization is larger than for lower-temperature treatments. Crystallization volume is concentrated in a layer on the surface and is more expanded in the bulk and when dendritic growth decreases. As shown in Table III, the SEM/EDX microanalysis conducted in both types of crystals demonstrates their pyroxene and feldspar nature enriched in $\mathrm{CaO}$.
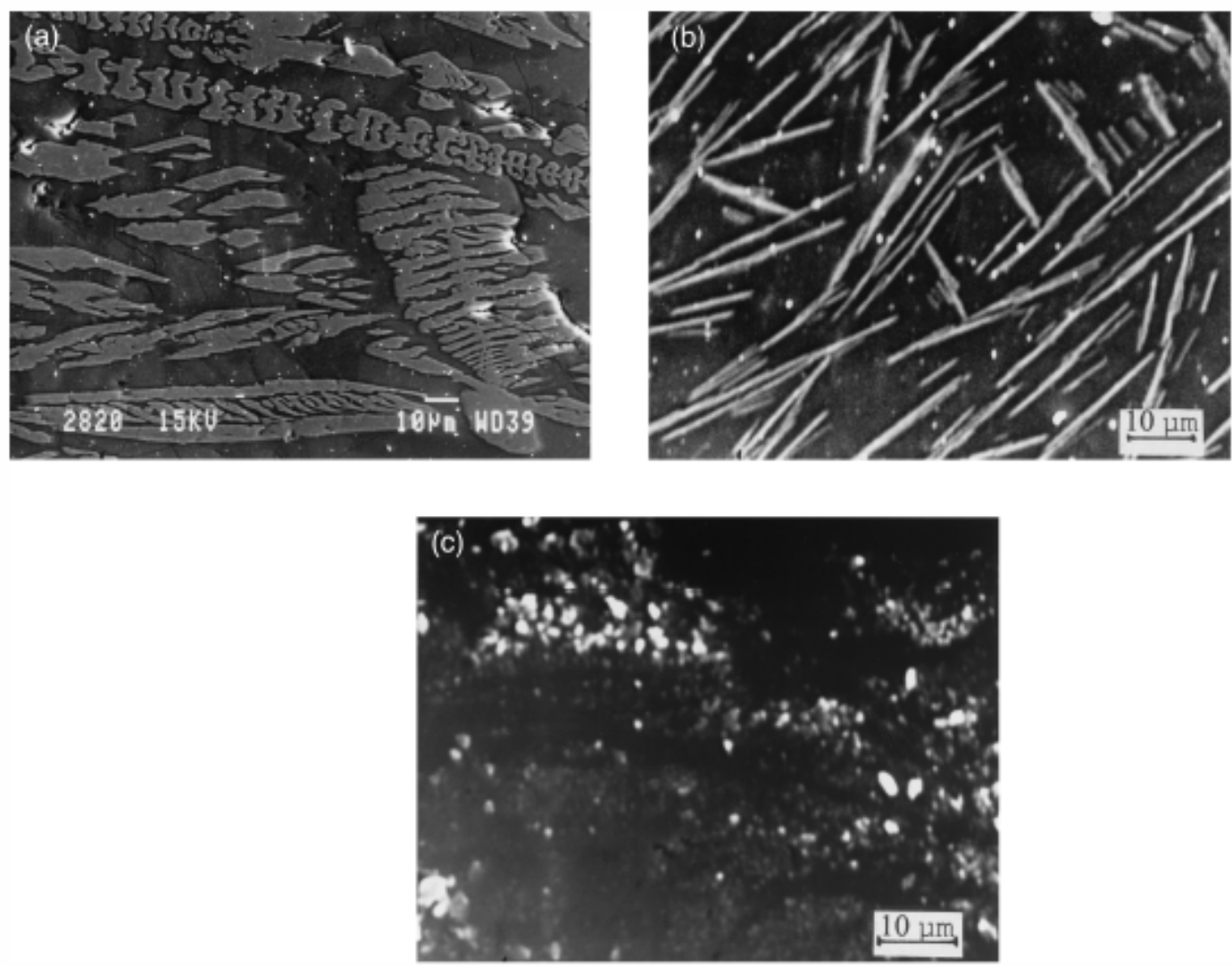

Fig. 6. SEM micrographs from glass-ceramics obtained after several thermal treatments: (a) 4AP glass heat-treated at $1100^{\circ} \mathrm{C}$ for $2 \mathrm{~h}$, (b) $5 \mathrm{AP}$ glass heat-treated at $900^{\circ} \mathrm{C}$ for $30 \mathrm{~min}$, and (c) $6 \mathrm{AP}$ glass heat-treated at $900^{\circ} \mathrm{C}$ for $16 \mathrm{~h}$. 
L. Barbieri, I. Lancellotti, T. Manfredini, G.C. Pellacani, J.Ma. Rincón, M. Romero. Nucleation and Crystallization of New Glasses from Fly Ash Originating from Thermal Power Plants Journal of the American Ceramic Society, 84 (2001) 8, 1851-1858

DOI: 10.1111/j.1151-2916.2001.tb00926.x

Figures 6(b) and (c) show that glass-ceramics obtained from 5AP and 6AP glasses contain elongated crystals, which, as has been demonstrated by XRD analysis, are wollastonite acicular crystals. ${ }^{13}$ Wollastonite has a phase transformation from parawollastonite ( $\alpha$ form, which is monoclinic) to pseudowollastonite ( $\beta$ form, which is triclinic) at high temperatures, such as $1120^{\circ} \mathrm{C}$. In these glasses, wollastonite is formed at $900^{\circ} \mathrm{C}$ in the low temperature form ( $\alpha$ form) with a texture of very thin/acicular crystals. Beams of branched acicular cystals of wollastonite can be seen in glass-ceramics from the 5AP original glass growing from the surface (Fig. 6(b)) and showing high $\mathrm{SiO}_{2}$ and $\mathrm{CaO}$ contents. Very small rounded white contrast crystallites are observed between the acicular crystals, which also are composed of wollastonite but have a lower $\mathrm{SiO}_{2}$ content. These can be the transversal sections of the acicular crystals randomly oriented inside the glass-ceramic. EDX analysis allows us to distinguish the relative percentage of the elements in the wollastonite and in the residual glassy phase (Table III), which is highly rich in $\mathrm{SiO}_{2}$.

Table III. Microanalysis Obtained by SEM/EDX on Phases Precipitated in 4AP, 5AP, and 6AP Glass-Ceramics

\begin{tabular}{|c|c|c|c|c|c|c|c|c|}
\hline \multirow[b]{2}{*}{ Precipitated phase } & \multicolumn{8}{|c|}{ Composition (\%) } \\
\hline & $\mathrm{SiO}_{2}$ & $\mathrm{Al}_{2} \mathrm{O}_{3}$ & $\mathrm{CaO}$ & $\mathrm{MgO}$ & $\mathrm{Na}_{2} \mathrm{O}$ & $\mathrm{K}_{2} \mathrm{O}$ & $\mathrm{Fe}_{2} \mathrm{O}_{3}{ }^{+}$ & $\mathrm{TiO}_{2}$ \\
\hline $\begin{array}{l}\text { Pyroxene crystals } \\
\text { Feldspar crystals } \\
\text { Residual glassy matrix }\end{array}$ & $\begin{array}{l}63.56 \\
72.44 \\
63.60\end{array}$ & $\begin{array}{r}8.33 \\
16.71 \\
8.29\end{array}$ & $\begin{array}{l}4 \text { AP. glas } \\
18.36 \\
6.36 \\
18.87\end{array}$ & $\begin{array}{l}c \\
5.49 \\
0.47 \\
5.45\end{array}$ & 2.07 & $\begin{array}{l}0.09 \\
0.70 \\
0.17\end{array}$ & $\begin{array}{l}3.48 \\
1.04 \\
3.14\end{array}$ & $\begin{array}{l}0.69 \\
0.21 \\
0.48\end{array}$ \\
\hline $\begin{array}{l}\text { Wollastonite crystals } \\
\text { Residual glassy matrix }\end{array}$ & $\begin{array}{l}74.77 \\
90.35\end{array}$ & $\begin{array}{l}1.03 \\
3.26\end{array}$ & $\begin{array}{l}5 \text { A.P glas } \\
23.15 \\
3.03\end{array}$ & $\begin{array}{l}c^{c} \\
0.38 \\
0.89\end{array}$ & $\begin{array}{l}0.60 \\
1.39\end{array}$ & 0.41 & $\begin{array}{l}0.07 \\
0.53\end{array}$ & 0.14 \\
\hline $\begin{array}{l}\text { Wollastonite crystals } \\
\text { Pyroxene crystals } \\
\text { Residual glassy matrix }\end{array}$ & $\begin{array}{l}71.86 \\
76.36 \\
87.11\end{array}$ & $\begin{array}{l}2.07 \\
1.97 \\
5.62\end{array}$ & $\begin{array}{l}\text { 6AP glas } \\
24.50 \\
14.80 \\
3.21\end{array}$ & $\begin{array}{l}c 0.52 \\
5.00 \\
1.03\end{array}$ & $\begin{array}{l}0.39 \\
0.12 \\
1.47\end{array}$ & $\begin{array}{l}0.22 \\
0.23 \\
0.41\end{array}$ & $\begin{array}{l}0.31 \\
1.32 \\
1.00\end{array}$ & $\begin{array}{l}0.13 \\
0.20 \\
0.15\end{array}$ \\
\hline
\end{tabular}

Glass-ceramics from the 6AP original glass also contain wollastonite acicular crystals, some of these with perpendicular growth from the surface (Fig. 6(c)), but showing less branching and having a lower volume fraction in the bulk of the material. After heat treatment at $900^{\circ} \mathrm{C}$, it is evident that an additional phase of dendritic pyroxene and precipitation of rounded crystals with very high contrast appear with increasing time of thermal treatments. As demonstrated by EDX microanalysis (Table III), the composition of the wollastonite phase precipitated in the 6AP glass is very similar to that obtained in the 5AP glass, while the pyroxene rounded crystals are different in composition from the 4AP glass. The pyroxene crystals contain less $\mathrm{Al}_{2} \mathrm{O}_{3}$ and 
L. Barbieri, I. Lancellotti, T. Manfredini, G.C. Pellacani, J.Ma. Rincón, M. Romero. Nucleation and Crystallization of New Glasses from Fly Ash Originating from Thermal Power Plants Journal of the American Ceramic Society, 84 (2001) 8, 1851-1858

DOI: $10.1111 / j .1151-2916.2001 . t b 00926 . x$

$\mathrm{Fe}_{2} \mathrm{O}_{3}$ in $6 \mathrm{AP}$ glass-ceramic obtained at $900^{\circ} \mathrm{C}$ for $16 \mathrm{~h}$ than the ones in $4 \mathrm{AP}$ glass-ceramic, the former being closer to diopside composition. Microstructural observations clearly indicate that crystallization volume decreases when the length of thermal treatment is increased.

\section{Conclusions}

For the first time, the capability of fly ash from Spanish thermal power plants to produce glasses and glass-ceramics has been demonstrated. The vitrification of such fly ash, in this case from As Pontes, Galicia, was first theorized through calculations conducted by the Ginsberg, RaschinTschetveritkov, and Lebedeva methods and later confirmed through the determination of TTT curves by considering the relative volume of crystallization using XRD as reference. Final vitrification of this Spanish fly ash was achieved, and original glass compositions were prepared from mixtures of fly ash and dolomite residues from the zinc mining operations in northern Spain. Two families of glasses were produced: the first was more stable and susceptible to wollastonite crystals containing glass-ceramics produced by controlled thermal treatments. The second was more devitrifiable, presenting a higher iron oxide content ( $6 \%)$ and giving rise to glass-ceramics composed of pyroxene and anorthite crystals. In all the fly ash glass compositions investigated, no induction time of nucleation and crystallization was detected. Crystallization growth was very fast, occurring from very short thermal treatment times. Relative crystallization rate curves showed that feldspar growth was lower than pyroxene growth in the 4AP glass, because the pyroxene had dendritic microstructure. Wollastonite growth obtained from 5AP and 6AP glasses occurred in a very narrow range around $1000^{\circ} \mathrm{C}$, with acicular branching of wollastonite crystals.

\section{Acknowledgment}

Use of the facilities of the Electron Microscopy Laboratories of the CENIM (CSIC, Madrid, Spain) and the Institute of Aerospatial Science and Technology (INTA, Torrejon, Spain) is recognized. 
L. Barbieri, I. Lancellotti, T. Manfredini, G.C. Pellacani, J.Ma. Rincón, M. Romero. Nucleation and Crystallization of New Glasses from Fly Ash Originating from Thermal Power Plants Journal of the American Ceramic Society, 84 (2001) 8, 1851-1858

DOI: 10.1111/j.1151-2916.2001.tb00926.x

\section{References}

1. "Directive of Atmospheric Emission Limitations of Determined Contaminants from Large Combustion Facilities,” (88/609/ECC). Official Diary of European Communities L336, Dec. 1988.

2. M. Puccio, Le Ceneri di Carbone. ITEC, Milan, Italy, 1983.

3. E. A. Mari, "El Desarrollo de las Tecnologías de Vitrificación para la Inmovilización de Residuos Radiactivos,” Bol. Soc. Esp. Ceram. Vid., 25 [5] 307-14 (1986).

4. J. Ma. Rincón, Glasses and Glass-Ceramics for Nuclear Waste Management, $2^{\text {nd }}$ ed. Centro de Investigaciones Energéticas Medioambientales y Tecnológicas (CIEMAT) y SEVC, Spain, 1991.

5. M. C. Alonso and M. P. de Luxán, Aplicaciones de las Cenizas Volantes en el Campo de la Construcción. Experiencia Española. ASINEL and Instituto E. Torroja, CSIC, Madrid, Spain, 1995.

6. Cenizas Volantes en Bases y Subbases de Carreteras, Programa de Investigación y Desarrollo Electrotécnico (PIE). UNESA/ASINEL, Madrid, Spain, 1987.

7. A. Kipka, B. Luckscheiter, and W. Lutze, "Melting of Fly Ashes and Product Properties," Glastech. Ber., 66 [9] 215-20 (1993).

8. J. Ma. Rincón and M. Romero, "Glass-Ceramics as Building Materials," Mater. Construcción, 46 [242-43] 91-106 (1996).

9. Ch. Igonet, “Les Matiéres Premiéres des Vitrocéramiques,” Verres Refract., 29 [4 -5] 17791 (1975).

10. M. Hidalgo and J. Ma. Rincón, "Fundamentos de la Inmovilización de los Residuos Radiactivos en Matrices Vítreas y Vitrocerámicas,” Bol. Soc. Esp. Ceram. Vid., 26 [4] 227-34 (1987).

11. D. E. Clark, H. Christensen, and L. Werme, "Effects of Flow on Corrosion and Surface Film Formation on an Alkali Borosilicate Glass”; pp. 19-29 in Advances in Ceramics, Vol 
L. Barbieri, I. Lancellotti, T. Manfredini, G.C. Pellacani, J.Ma. Rincón, M. Romero. Nucleation and Crystallization of New Glasses from Fly Ash Originating from Thermal Power Plants Journal of the American Ceramic Society, 84 (2001) 8, 1851-1858

8. Nuclear Waste Management. Edited by G. G. Wicks and W. A. Ross. American Ceramic Society, Columbus, Ohio, 1984.

12. M. Hidalgo, P. Callejas, and J. Ma. Rincón, "Microstructure Characterization of Basalt Glass-Ceramics”; pp. 117-26 in Ceramic Microstructure '86: The Role of Interfaces. Edited by J. Pask and A. Evans. Plenum, Berkeley, CA, 1988.

13. L. Barbieri, T. Manfredini, Y. Queralt, M. Romero, and J. Ma. Rincón,“Vitrification of Fly Ash from Thermal Power Stations,” Glass Technol., 38 [5] 65-170 (1997).

14. Queralt, X. Querol, A. López-Soler, and F. Plana, "Use of Coal Fly Ash for Ceramics: a Case Study from a Spanish Large Power Station,” Fuel, 76 [8] 787-91 (1997).

15. de Vicente Mingarro, "Estudio de los Mecanismos de Nucleación y Cristalización en Vidrios Obtenidos a Partir de Rocas Basalticas Canarias”; Doctoral Thesis. University of Madrid, Madrid, Spain, 1992.

16. Queralt, "Dinamica Mineral de los Procesos de Devitrificación en Vidrios Basálticos ”; Doctoral Thesis. University of Barcelona, Barcelona, Spain, 1988.

17. F. Branda, A. Buri, A. Marotta, and S. Saiello, “Activation Energy for the Crystallization of Glass from the DDTA Curves,” J. Mater. Sci., 17, 105-108 (1982).

18. (a)J. Voldan, “Cristallisation Controlée des Roches Fondues,” Verres Refract., 19 [3] 23033 (1965). (b)“Studium Kristalice Skla o Slozeni Anortiru Pomoci DTA,” Sklar Keram., 334-38 (1979).

19. A. García Verduch, "Materiales Obtenidos a Partir da Rocas y Escorias Fundidas"; pp. 120-51 in Jornadas Cientýfficas sobre Cerámica y Vidrio. Ed Seccion de Ciencias Basica del la Soc. Esp. Ceram. Vidr. y Universidad de Ovied, Universidad de Oviedo, Oviedo, Spain, 1980.

20. G. A. Raschin and S. D. Tschetveritkov, "Método Petroquímico para Evaluar Materias Primas Petrúrgicas,” Izv. Rev. Inv. Geol. Prospec., 9, 71-79 (1964).

21. M. Kanazirsky and Y. Yotzo, "Etude Preliminare sur les Posibilités Geologiques de une Production au Maroc de Basaltes Fondus,” Mines Géol., 36, 49-56 (1972).

22. A. Morse, Basalt Phase Diagrams; pp. 9-10. Springer-Verlag, New York, 1980. 
L. Barbieri, I. Lancellotti, T. Manfredini, G.C. Pellacani, J.Ma. Rincón, M. Romero. Nucleation and Crystallization of New Glasses from Fly Ash Originating from Thermal Power Plants Journal of the American Ceramic Society, 84 (2001) 8, 1851-1858

23. D. R. Uhlman, “A Kinetic Treatment of Glass Formation,” J. Non-Cryst. Solids, 7, 337-48 (1972).

24. J. Ma. Rincon, "Principles of Nucleation and Controlled Crystallization of Glasses," Polym.-Plast. Technol. Eng., 31, 309-57 (1992).

25. Gutzow and J. Schmelzer, The Vitreous State, Thermodynamics, Structure, Rheology and Crystallization. Springer-Verlag, Berlin, Germany, 1995.

26. E. V. Ermolaeva and I. V. Skorobogatova, "Infrared Transmission Spectra of Aluminosilicate Melts Quenched to The Glassy State”; pp. 30-33 in The Structure of Glass, Vol. 7. Consultants Bureau, New York, 1966.

27. M. Romero and J. Ma. Rincon, "Surface and Bulk Crystallization of Glass-Ceramics in the $\mathrm{Na}_{2} \mathrm{O}-\mathrm{CaO}-\mathrm{ZnO}-\mathrm{PbO}-\mathrm{Fe}_{2} \mathrm{O}_{3}-\mathrm{Al}_{2} \mathrm{O}_{3}-\mathrm{SiO}_{2}$ System Derived from a Goethite Waste,” J. Am. Ceram. Soc., 82 [ 5] 1313-18 (1999). 